\title{
PENGEMBANGAN LKS BERBASIS LINGKUNGAN MATERI PERUBAHAN FISIKA DAN KIMIA IPA TERPADU DI KELAS VII SMPN 2 PULAU MALAN TAHUN AJARAN 2020/2021
}

\author{
LISNAWATI \\ Program Magister Pendidikan Kimia, Universitas Palangka Raya \\ lisnawati1992@gmail.com
}

\begin{abstract}
ABSTRAK
Meningkatkan penguasaan konsep dan membangkitkan minat belajar siswa salah satunya dapat menggunakan Lembar Kerja Siswa (LKS) yang dikembangkan atau dirancang sendiri oleh guru. Pencapaian tujuan belajar akan maksimal jika pengembangan tersebut dapat dibuat berdasarkan kebutuhan dan kemampuan siswa, kondisi sekolah serta lingkungan. LKS berbasis lingkungan dirancang dengan materi dan contoh peristiwa yang sering dijumpai /ada di lingkungan siswa hal ini untuk menjadikan pembelajaran lebih nyata bagi siswa sehingga memberikan pengalaman belajar dengan baik dan mudah bagi siswa. Pengembangan ini menggunakan model 4D (Define, Design, Development, Dissemination. Hasil penilaian kelayakan LKS: keterbacaan Ahli 85,76\% (sangat layak), keterbacaan kelompok 87,16\% (sangat layak) dan keterbacaan perorangan 83,50\% (sangat layak). Penggunaan LKS Berbasis Lingkungan dinyatakan efektif untuk meningkatkan penguasaan konsep siswa, hal ini terlihat dari perubahan antara nilai preetest dan posttes dengan hasil perhitungan $\mathrm{N}$-Gain 0,52. Ketuntasan klasikal sebesar 90\% siswa yang tuntas TPK yang tuntas sebanyak 6 TPK $(85,7 \%)$ dan TPK yang tidak tuntas sebanyak 1 TPK $(14,3 \%)$ dari 7 TPK. Terdapat juga peningkatan minat belajar siswa antara sebelum dan sesudah melalui proses pembelajaran menggunakan LKS Berbasis Lingkungan, hal ini dapat terlihat dari perhitungan N-Gain berdasarkan indikator yang dinilai: (1) Rasa tertarik, senang dan bersemangat sebesar 0,69, (2) Kegiatan Belajar sebesar 0,74 dan (3) Cara mengikuti pelajaran sebesar 0,63. Jika dilihat dari butir setiap aspek penilaian dengan kategori tinggi $=25 \%$ dan sedang $=75 \%$.
\end{abstract}

Kata Kunci: LKS Berbasis Lingkungan, penguasaan konsep,minat belajar

\section{PENDAHULUAN}

Seorang guru berperan penting dalam meningkatkan kualitas proses pembelajaran dan hasil belajar siswa. Oleh karena itu, guru harus bijaksana dalam menentukan suatu strategi belajar yang dapat menciptakan situasi dan kondisi kelas yang kondusif agar proses belajar mengajar dapat berlangsung efektif dan efisien sesuai dengan tujuan pembelajaran dapat dicapai secara maksimal. Strategi pembelajaran perlu dikembangkan dengan menekankan pada kegiatan belajar siswa aktif (active learning) dan melakoninya langsung (learning by doing) melalui pembelajaran kontekstual (Contextual Teaching and Learning).

Ada kecenderungan pemikiran bahwa siswa akan belajar lebih baik jika lingkungan diciptakan lebih alamiah. Belajar akan lebih bermakna jika siswa mengalami apa yang dipelajarinya, bukan mengetahuinya. Salah satu cara untuk membantu siswa memahami dan memudahkan guru dalam mengajarkan konsep-konsep tersebut adalah dengan mengaitkan materi pelajaran dengan pengalaman nyata dalam kehidupan sehari-hari. Oleh karena itu diperlukan pembelajaran yang dapat membelajarkan siswa sehingga dapat tertarik dengan kimia serta sebagai bekal bagi siswa untuk memecahkan masalah yang berkaitan dengan kimia.

Kondisi pembelajaran selama ini dimana siswa hanya sebagai objek pembelajaran yang menerima informasi dari guru merupakan kendala yang relatif sulit untuk diubah. Namun demikian, ada beberapa cara yang dapat digunakan guru untuk dapat mengaktifkan siswa, salah satunya dengan melalui penggunaan LKS. Penggunaan LKS diharapkan mampu mengubah kondisi pembelajaran dari yang biasanya guru berperan menentukan "apa yang dipelajari" menjadi "bagaimana menyediakan dan memperkaya pengalaman belajar siswa". Pengalaman 
belajar siswa dapat diperoleh melalui serangkaian kegiatan untuk mengeksplorasi lingkungan melalui interaksi aktif dengan teman, lingkungan, dan nara sumber lain (Salirawati, 2010).

Penyajian pembelajaran kimia dengan menggunakan LKS menuntut adanya partisipasi aktif dari para siswa, karena LKS merupakan bentuk usaha guru untukmembimbing siswa secara terstruktur, melalui kegiatan yang mampu memberikan dayatarik kepada siswa untuk mempelajari kimia. Melalui pembelajaran dengan LKS keefektifan proses belajar mengajar dapat ditingkatkan. Pada kenyataannya, meskipun di lapangan banyak ditemukan berbagai bentuk LKS, namun guru kurang mengetahui bagaimana kriteria LKS yang baik yang dapat digunakan dalam membantu mencapai tujuan pembelajaran (Salirawati, 2010).

Fakta yang terjadi di lapangan sebagai salah satu kendala yang timbul adalah materi pokok kimia dikombinasikan dengan materi pokok fisika dan biologi. Sedangkan guru yang mengajarkan mata pelajaran IPA Terpadu ini hanya satu orang, dan belum tentu bisa mengajarkan materi tentang kimia, fisika ataupun biologi dengan baik. Sehingga perlunya bahan ajar yang dirancang lebih dulu secara maksimal misalnya berupa LKS sebagai penunjang proses pembelajaran. Hasil penelitian menunjukkan bahwa siswa mendapatkan nilai $\geq 64$, siswa yang tuntas $84,21 \%$ dan keaktifan siswa mencapai kriteria sedang, tinggi, dan sangat tinggi. Guru dan siswa memberikan tanggapan yang sangat baik terhadap penerapan LKS berbasis lingkungan. (Natalia, 2011)

Sejalan dengan beberapa pendapat ahli di atas, alasan mengapa peneliti memilih pengembangan LKS berbasis lingkungan salah satunya karena sejalan dengan tujuan dari Asesmen Nasional saat ini yakni mengevaluasi keterampilan siswa dalam menerapkan pengetahuan serta konsep melalui berbagai konteks kehidupan. Membiasakan siswa dengan sistem belajar yang baru (kompetensi literasi dan numerasi) untuk mempersiapkan diri menghadapi Asesmen Kompetensi Minimum (AKM) yang sebentar lagi akan dilaksanakan. AKM ini juga mendorong siswa berpikir kritis untuk menyelesaikan masalah dalam kehidupan sehari-hari, hal ini juga berkaitan dengan syarat kecakapan abad 21 yang harus dimiliki oleh siswa SMP/MTS. Sehingga dengan menggunakan LKS berbasis lingkungan ini dapat menggiring siswa untuk selalu mengkaitkan dan menerapkan langsung kompetensi yang mereka peroleh kedalam kehidupan sehari-hari.

Kehadiran LKS berbasis lingkungan juga sangat membantu bagi sekolah yang di pinggiran kota maupun dipedalaman terutama sekolah-sekolah yang baru berdiri khususnya SMPN 2 Pulau Malan yang belum memiliki Laboratorium.kemudian ditinjau dari karakteristik materi- materi kimia yang dipelajari di SMP adalah materi yang berhubungan dengan kehidupan sehari-hari. Menurut Saya yang paling mendasar dari materi kimia lanjutan adalah materi Perubahan Fisika dan Kimia pada kelas VII SMP. Kemudian LKS yang dikeluarkan penerbit kebanyakan masih belum merangkum kebutuhan dalam proses pembelajaran siswa dengan kondisi yang berbeda-beda pada tiap sekolah sehingga perlu dikembangkan lagi oleh guru sebelum digunakan dalam pembelajaran.Berdasarkan beberapa alasan tersebut, maka dalam penelitian ini dikembangkan lembar kerja siswa (LKS) berbasis lingkungan pada materi perubahan fisika dan kimia - IPA terpadu kelas VII SMP di SMPN 2 Pulau Malan.

\section{METODE PENELITIAN}

Penelitian ini menggunakan jenis pengembangan (Research and Development), yaitu suatu proses yang digunakan untuk mengembangkan dan memvalidasi produk-produk yang digunakan dalam pembelajaran yakni LKS berbasisi Lingkungan. Thiagarajan mengemukakan bahwa, langkah-langkah penelitian dan pengembangan disingkat dengan 4D, yaitu: Define (Pendefinisian), berisi kegiatan untuk menetapkan produk apa yang akan dikembangkan, beserta spesifikasinya. Design (Perancangan), berisi kegiatan untuk membuat rancangan terhadap produk yang telah ditetapkan. Development (Pengembangan) berisi kegiatan membuat rancangan menjadi produk dan menguji validitas produk secara berulangulang sampai dihasilkan produk sesuai dengan spesifikasi yang ditetapkan. Dissemination 
(Diseminasi) berisi kegiatan menyebarluaskan produk yang telah teruji untuk dimanfaatkan orang lain.Adapun tahapan penelitian sebagai berikut:

\section{a. Tahap define (pendefinisian)}

Pada tahap define (pendefinisian) yang dilakukan adalah identifikasi masalah, analisis kebutuhan, analisis materi dan analisis tugas. Pada analisis awal-akhir dimana dalam tahap ini dilakukan analisis kebutuhan yang ditinjau berdasarkan tuntutan kurikulum 2013 yaitu siswa harus mampu berpikir ilmiah. Kemudian ditambah lagi adanya Assesmen Nasional yang menuntut siswa untuk selalu beranalisis dan menerapkan ilmunya dalam pengalaman sehari-hari sehingga hal ini sejalan dengan dikembangkannya LKS berbasis lingkungan.

\section{b. Tahap design (perancangan)}

Tahap ini dilakukan penyususan tes/ evaluasi, pemilihan media, pemilihan format dan rancangan LKS yang akan dikembangkan. Tes disusun untuk mengukur penguasaan konsep di tinjau dari peningkatan hasil kompetensi pengetahuan siswa. Pengembangan instrumen berorientasi lingkungan yang meliputi keterampilan bahasa simbolik, pemodelan matematika, membangun konsep, konsistensi logika, hubungan sebab akibat dan inferensi logika. Tes disusun dalam bentuk soal uraian berjumlah 12 soal. Karakteristik LKS yang dikembangkan sesuai dengan karakteristik siswa, lingkungan dan konsep materi perubahan fisika dan kimia. Format penulisan LKS yang dipilih adalah berbahasa Indonesia, berbentuk portral, berwarna dan kertas A4. Format tulisan ukuran 11 tipe comic sain MS. Pemilihan jenis tulisan ini agar lebih menarik secara tampilan, tujuannya siswa lebih semangar untuk mengerjakannya.

\section{c. Tahap develop (pengembangan)}

Tahap pengembangan ini meliputi penyusunan instrumen penilaian produk, pemilihan validator, desain revisi, uji keterbacaan perorangan, uji keterbacaan kelompok, lebih jelasnya alur secara umum terlihat pada gambar bagan berikut ini.

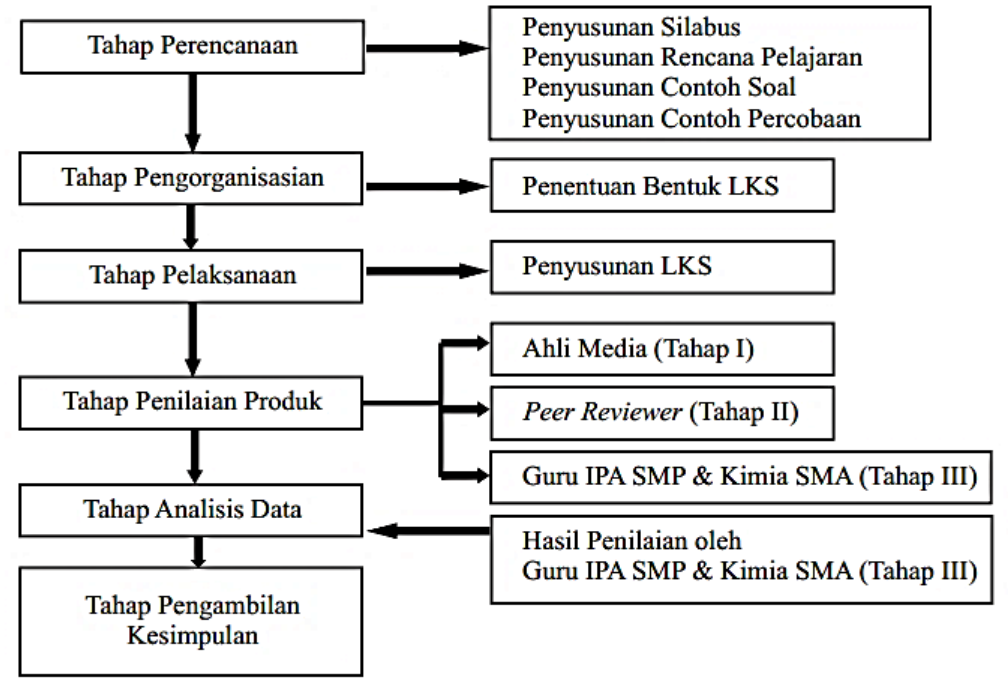

\section{d. Tahap disseminate (penyebaran)}

Gambar 1: Bagan prosedur pengembangan

Pada penelitian ini hanya dilakukan diseminasi terbatas, yaitu dengan menyebarluaskan dan mempromosikan produk akhir kepada guru IPA di sekolah dan anggota MGMP IPA Kabupaten Katingan. Guru yang menerima mengisi form secara online untuk melakukan penilaian kebermanfaatan dari LKS yang telah dikembangkan melalui link: http://forms.gle/t6rXgnZH45tDMvNk9 


\section{HASIL PENELITIAN DAN PEMBAHASAN}

\section{a. Hasil Penelitian}

1) Hasil Data Uji Coba Instrumen

Instrumen yang digunakan dalam penelitian ini berupa soal tes uraian yang sebelumnya di validasi secara konten per butir soal oleh validator (tahap I), kemudian diujicobakan kepada siswa yang telah mendapatkan materi Perubahan Fisika dan Kimia yaitu siswa kelas VII A (tahap II). Instrumen yang diujicobakan berupa 12 soal uraian. Hasil tes yang telah diujicobakan kemudian dianalisis terlebih dahulu yang nantinya akan dijadikan sebagai soal pretest dan posttest. Berikut ini analisis soal instrumen yang meliputi validitas, reliabilitas, tingkat kesukaran, dan daya beda.

Tabel 1. Rekapitulasi Hasil Uji Coba Instrumen

\begin{tabular}{cccccccc}
\hline $\begin{array}{c}\text { No. } \\
\text { Soal }\end{array}$ & Validitas & Kategori & $\begin{array}{c}\text { Indeks } \\
\text { Kesukaran }\end{array}$ & Kategori & $\begin{array}{c}\text { Daya } \\
\text { Pembeda }\end{array}$ & Kategori & Keterangan \\
\hline 1 & 0,67 & Valid & 0,73 & Mudah & 0,24 & Cukup & Digunakan \\
2 & 0,69 & Valid & 0,68 & Sedang & 0,28 & Cukup & Digunakan \\
3 & 0,45 & Valid & 0,68 & Sedang & 0,15 & Jelek & Diperbaiki \\
4 & 0,83 & Valid & 0,67 & Sedang & 0,44 & Baik & Digunakan \\
5 & 0,69 & Valid & 0,65 & Sedang & 0,24 & Cukup & Digunakan \\
6 & 0,51 & Valid & 0,63 & Sedang & 0,22 & Cukup & Digunakan \\
7 & 0,81 & Valid & 0,65 & Sedang & 0,46 & Baik & Digunakan \\
8 & 0,49 & Valid & 0,66 & Sedang & 0,22 & Cukup & Digunakan \\
9 & 0,72 & Valid & 0,67 & Sedang & 0,31 & Cukup & Digunakan \\
10 & 0,75 & Valid & 0,63 & Sedang & 0,24 & Cukup & Digunakan \\
11. & 0,66 & Valid & 0,66 & Sedang & 0,26 & Cukup & Digunakan \\
12 & 0,81 & Valid & 0,61 & Sedang & 0,42 & Baik & Digunakan \\
\hline
\end{tabular}

2) Kelayakan LKS berbasis lingkungan

a) Keterbacaan Ahli

Penilaian Keterbacaan Ahli dari 5 orang validator diperoleh bahwa: rata-rata keseluruhan aspek sebesar 85,76 (sangat layak). Adapun perolehan dari masingmasing aspek sebagai berikut:

Tabel 2. Hasil Penilaian Keterbacaan Ahli

\begin{tabular}{llll}
\hline No & Aspek & Rata-rata & Kategori \\
\hline 1 & Deskripsi LKS & $85 \%$ & Sangat layak \\
2 & Prasyarat Pengetahuan & $75 \%$ & Layak \\
3 & Petunjuk atau Arahan untuk siswa & $86,25 \%$ & sangat layak \\
4 & Tujuan Pembelajaran & $95 \%$ & sangat layak \\
5 & Alur Kegiatan Pembelajaran & $85 \%$ & sangat layak \\
6 & Kegiatan pada Fase Pembelajaran & $88,33 \%$ & sangat layak \\
\hline
\end{tabular}

b) Keterbacaan secara kelompok

Penilaian keterbacaan kelompok ini diberikan kepada tujuh kelompok kecil dengan masing-masing tiga anggota di dalamnya. Adapun sajian data secara sederhana tertera pada gambar diagram hasil analisis di bawah ini: 


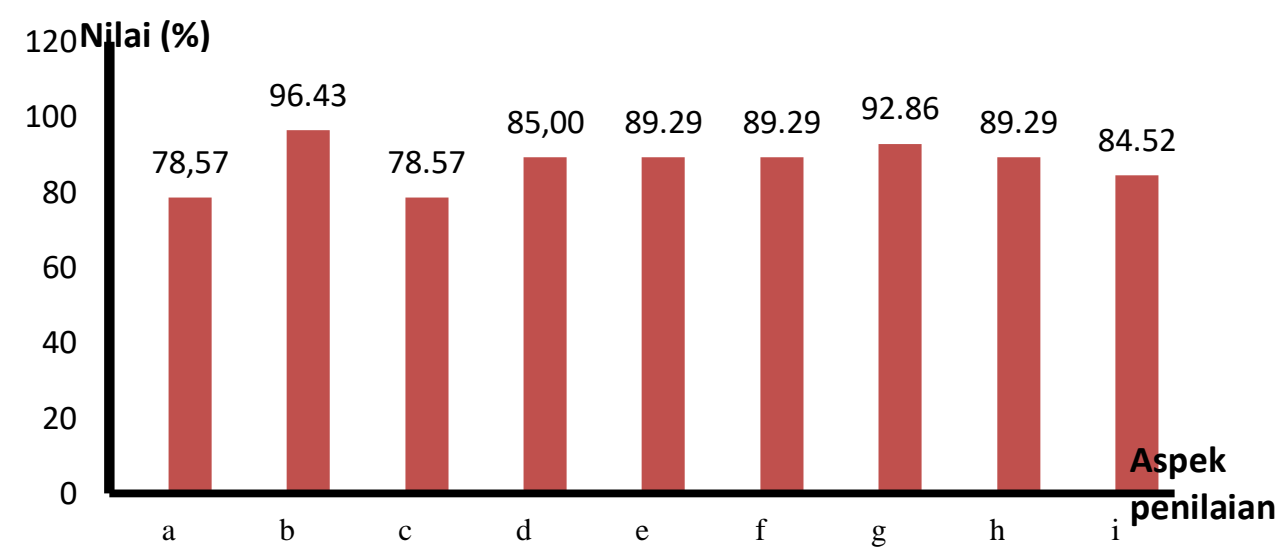

Gambar 2: Diagram hasil analisis penilaian keterbacaan kelompok

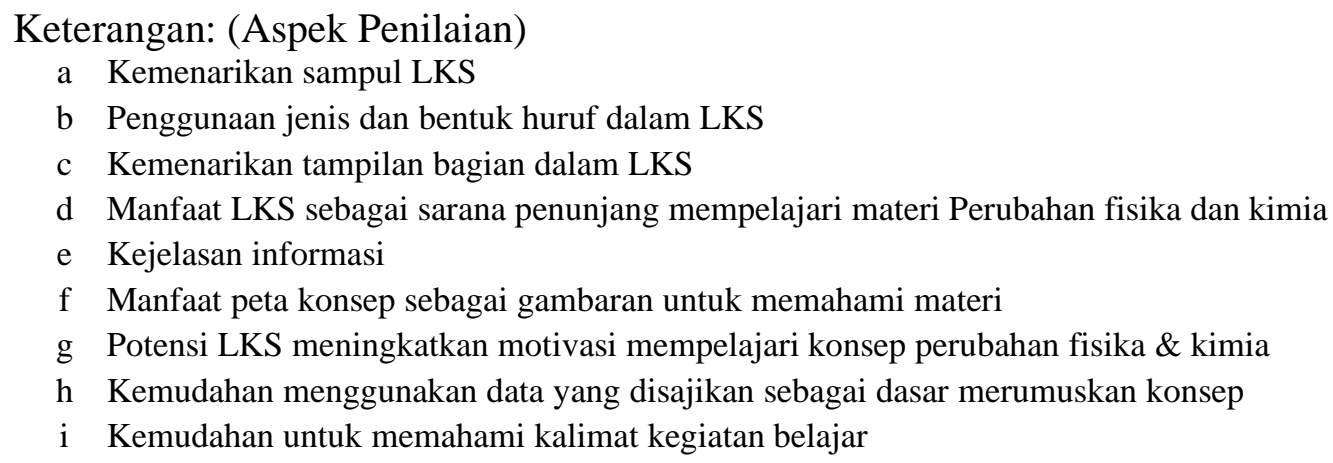

c) Keterbacaan Perorangan dengan jumlah responden 30 orang diperoleh bahwa hasil rata-rata seluruh aspek $83,50 \%$ (sangat layak). Adapun penilaian setiap aspek: Kemenarikan sampul 83,33\% (sangat layak), Kemenarikan tampilan bagian dalam LKS 83,33\% (sangat layak), Kemudahan memahami bahasa yang digunakan dalam LKS $81,67 \%$ (sangat layak), Kemudahan memahami langkah pembelajaran pada LKS 85\% (sangat layak), Potensi meningkatkan motivasi untuk mempelajari LKS $84,17 \%$ (sangat layak).

3) Peningkatan penguasaan konsep

Penggunaan LKS Berbasis Lingkungan dinyatakan efektif untuk meningkatkan penguasaan konsep siswa, hal ini terlihat dari hasil perhitungan $\mathrm{N}-$ Gain perubahan nilai siswa antara pretest dan postes rata-rata keseluruhan 0,55 (sedang) dengan kategori: tinggi $=16,7 \%$, sedang $=73,3 \%$ dan rendah $=10 \%$. Hasil belajar kognitif siswa dengan pembelajaran menggunakan LKS berbasis lingkungan terdapat 27 orang siswa yang tuntas dan 3 orang tidak tuntas dari 30 siswa. Pembelajaran dikatakan tuntas karena diperoleh persentase $90 \%$ siswa yang tuntas dan mencapai standar ketuntasan klasikal yang ditetapkan yaitu $\geq 75 \%$. TPK yang tuntas sebanyak 6 TPK $(85,7 \%)$ dan TPK yang tidak tuntas sebanyak 1 TPK $(14,3 \%)$ dari 7 TPK.

4) Minat Belajar Siswa

Terdapat peningkatan minat belajar siswa antara sebelum dan sesudah melalui proses pembelajaran menggunakan LKS Berbasis Lingkungan, hal ini dapat terlihat dari perhitungan N-Gain berdasarkan indikator yang dinilai: (1) Rasa tertarik, senang dan bersemangat sebesar 0,69, (2) Kegiatan Belajar sebesar 0,74 dan (3) Cara mengikuti pelajaran sebesar 0,63 . Jika dilihat dari butir setiap aspek penilaian dengan kategori tinggi $=25 \%$ dan sedang $=75 \%$. 


\section{b. Pembahasan}

1) Deskripsi Proses Belajar Mengajar Selama Penelitian

Penelitian dilaksanakan dikelas VII-B SMP Negeri 2 Pulau Malan dengan jumlah peserta didik sebanyak 30 orang. Kegiatan penelitian dilaksanakan 5 kali pertemuan, dengan rincian tiga kali pertemuan dilaksanakan kegiatan pembelajaran menggunakan LKS Berbasis Lingkungan dan dua kali pertemuan untuk melaksanakan pengukuran minat dan penguasaan konsep awal dan akhir. Selama pandemi semua kelas dibagi menjadi dua kelompok yaitu kelompok 1 tatap muka Senin-Rabu-Jumat dan kelompok 2 tatap muka Selasa-kamis-sabtu mulai pukul 08.00-10.00WIB. Kegiatan tersebut dapat dilihat pada tabel berikut:

2) Hasil Analisis Uji Coba Instrumen

Berdasarkan hasil perolehan uji coba instrumen semua soal (12 butir) dinyatakan valid dan reliabel. Indeks kesukaran soal diperoleh 11 soal dengan kategori sedang dan 1 soal dengan kategori mudah. Untuk daya pembeda 3 soal dengan kategori baik, 8 soal dengan kategori cukup dan 1 soal dengan kategori jelek (nomor soal: 3 ). Semua soal digunakan karena mempertimbangkan keterwakilan TPK. Untuk soal yang daya pembedanya jelek ini dilakukan revisi sesuai dengan arahan dari pembimbing dan validator soal.

3) Kelayakan LKS Berbasis Lingkungan yang Dikembangkan

Berdasarkan Tebel 2, hasil penilaian keterbacaan ahli untuk aspek Deskripsi LKS memperoleh nilai rata-rata 85,00 dengan kriteria sangat layak, hal ini karena LKS ini didesain dengan bahasa yang ringan agar lebih mudah diterima siswa kelas VII dan untuk menarik perhatian siswa. Aspek prasyarat Pengetahuan memperoleh nilai 75,00 dengan kriteria layak, hal ini berkaitan dengan proses pembelajaran seperti mengukur massa, sehingga siswa dituntut untuk mengetahui bagaimana cara menggunakan neraca dan guru wajib mengingatkan kembali tanpa dimasukan dalam LKS. Aspek petunjuk atau arahan untuk siswa memperoleh nilai 86,25 dengan kriteria sangat layak. Faktor penyebab perolehan nilai ini karena LKS ini dirancang agar siswa lebih mudah belajar secara mandiri sehingga petunjuk atau arahan dibuat dengan jelas dan tanpa siswa merasa diperintah namun diarahkan saja.

Aspek tujuan pembelajaran memperoleh nilai 95,00 dengan kriteria sangat layak. Hal ini disebabkan analisis kebutuhan berawal dari silabus hingga tersusunnya kisi-kisi LKS dan terbentuk LKS hasil akhir diusahakan sejalan. Alur kegiatan belajar memperoleh nilai 85,00 dengan kriteria sangat layak. Pada aspek ini dimuat penilaian kemenarikan tampilan dan kemudahan sisiwa untuk alur kegiatan yang runut. Tampilan dibuat semenarik mungkin agar menarik minat siswa untuk mempelajarinya. Aspek Kegiatan pada fase pembelajarannya memperoleh 88,33 dengan kriteria sangat layak. LKS ini disusun menyesuaikan kebutuhan dan tingkat kemampuan siswa sehingga setiap fasenya membantu siswa mengkontruksi pikirannya untuk memperoleh pengalaman belajar yang maksimal. Setiap fasenya juga menggunakan contoh peristiwa yang berbasis lingkungan sehingga mudan untuk diikuti.

4) Penguasaan konep

Trianto (2010:6) mengungkapkan bahwa tidak dapat disangkal, bahwa konsep merupakan suatu hal yang sangat penting, namun bukan terletak pada konsep itu sendiri, tetapi terletak pada bagaimana konsep itu dipahami oleh subjek didik. Pentingnya pemahaman konsep dalam proses belajar mengajar sangat mempengaruhi sikap, keputusan, dan caracara memecahkan masalah. Berdasarkan hal tersebut dapat disimpulkan bahwa penguasaan konsep adalah peningkatan hasil belajar yang diharapkan dalam proses pembelajaran. 
pada penelitian ini peningkatan penguasaan konsep dianalisis dari perolehan nilai preetest dan postes yang dibandingkan menggunakan perhitungan $\mathrm{N}=$ Gain yang akan disajikan secara sederhana menggunakan gambar diagram di bawah ini:

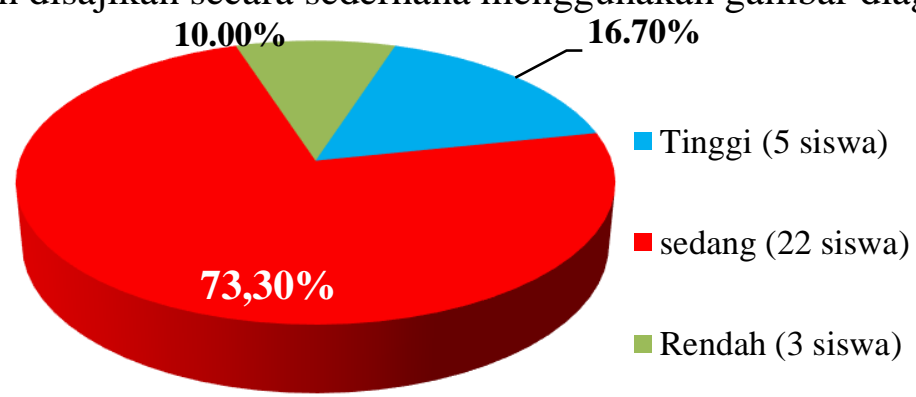

\section{Gambar 3 Diagram perolehan peningkatan penguasaan konsep}

Terlihat pada gambar di atas diperoleh sebanyak 5 orang siswa dengan nilai $\mid g>0,70$ kriteria tinggi. Faktor penyebabnya anak tersebut bukan anak yang selalu mendapat nilai tinggi tetapi selama proses pembelajaran memang lebih kritis dan mampu untuk diajak lebih berkonsentrasi terhadap LKSnya. Diperoleh sebanyak 22 orang siswa dengan nilai $0,30<|\mathrm{g}| \leq 0,70$ kriteria sedang hal ini sejalan dengan apa yang terjadi selama proses pembelajaran menggunakan LKS berbasis lingkungan berlangsung. Siswa merasa seru karena mendapat gaya belajar baru yang berbeda dengan buku paket sehari-hari. Bahasan di dalam LKS juga mudah dipahami karena sering ditemukan di lingkungan siswa. Diperoleh 3 orang siswa dengan nilai $|\mathrm{g}| \leq 0,30$ kriteria rendah hal ini dikarena kan siswa tersebut tidak hadir disalah satu pertemuan sehingga, adapula yang susah untuk diajak fokus dengan LKSnya karena belum lancar membaca.

5) Minat Belajar Siswa

Kondisi belajar mengajar yang efektif adalah adanya minat dan perhatian siswa dalam belajar. Minat merupakan suatu sifat yang relatif menetap pada diri seseorang. Minat besar sekali pengaruhnya terhadap belajar sebab dengan minat seseorang akan melakukan sesuatu yang diminatinya. Sebaliknya tanpa minat seseorang tidak mungkin melakukan sesuatu (Usman: 2011:11).

Pada penelitian ini perubahan minat siswa terlihat sangat signifikan perubahannya. Hal ini disebabkan banyak faktor diantaranya: siswa senang dengan metode atau cara belajar baru yang berbeda dengan buku paket yang mereka gunakan setiap harinya. LKS yang didesain khusus membuat siswa terlibat aktif selama proses pembelajaran sehingga memberikan pengalaman belajar yang bermakna pada siswa. Dalam LKS berbasis lingkungan memuat materi dan contoh peristiwa dibuat secara konkrit dan mudah mereka temukan dalam kehidupan sehari-hari sehingga siswa menganggap pembelajaran ini mudah dan tidak merasa terbebani selama proses pembelajaran berlangsung.

\section{KESIMPULAN}

Sesuai hasil penelitian dan pembahasan, maka dapat dikemukakan bahwa: (1) LKS berbasis lingkungan yang dikembangkan dinyatakan sangat layak $(85,76 \%)$ dan dapat digunakan dalam proses pembelajaran IPA kelas VII serta disebarkan kepada guru IPA yang membutuhkan. (2) Setelah melalui proses pembelajaran menggunakan LKS berbasisi lingkungan terdapat peningkatan penguasaan konsep siswa yang dilihat dari perubaha antara nilai pretes dan postes dengan analisis perhitungan $\mathrm{N}$ gain sebesar 0,52 dengan kategori sedang. (3) Terdapat juga peningkatan minat belajar siswa antara sebelum dan sesudah melalui proses pembelajaran menggunakan LKS Berbasis Lingkungan, hal ini dapat terlihat dari perhitungan N-Gain 
berdasarkan indikator yang dinilai: aspek Rasa tertarik, senang dan bersemangat sebesar 0,69, aspek kegiatan belajar sebesar 0,74 dan aspek Cara mengikuti pelajaran sebesar 0,63.

\section{DAFTAR PUSTAKA}

Abdurrahman, Mulyono. (2012). Pendidikan Bagi Anak Berkesulitan Belajar:Teori, Diagnosis, dan Remediasinya. PT.Rineka Cipta. Jakarta.

Adi, Agus., Made \& Made. (2012). Implementasi Model Pembelajaran Kooperatif Tipe Student Teams Achievement Divisions (STAD) Berbantuan LKS Terstruktur. Universitas Pendidikan Ganesha. Jakarta.

Dahar, R.W. (2011). Teori-teori Belajar. Erlangga.Jakarta .

Efriza, Mulyati, \& Megahati. (2013). Pengembangan Lembar Kerja Siswa (LKS) Biologi Berbasis Pendekatan Lingkungan Pada Materi Klasifikasi Makhluk Hidup Kelas VII SMP. Jurnal. STKIP PGRI Sumatera Barat. Padang.

Erviana, Lina., (2015) Pemanfaatan Media Pembelajaran Berbasis Lingkungan Sebagai Sarana Praktiukum IPA Untuk Siswa Meningkatkan Pemahaman Konsep Siswa Di SMPIT Ar-Rahman Pacitan”. Jurnal Dinamika Pendidikan Dasar, Vol. 7, September (2015) 71-77, h. 72-73. Pacitan.

Eli, R., Endang, W., \& Regina, T. (2019). Pengembangan Lembar Kerja Siswa (LKS) Mata Pelajaran Sains Kimia Untuk SMP. Jurnal. Universitas Negeri Yogyakarta. Yogyakarta.

Ferliyanti, Venny. (2017). Pengembangan Lembar Kerja Siswa Berbasis Inkuiri Terbimbing pada Materi Garam Hidrolisis. Skripsi Sarjana. tidak diterbitkan. Universitas Lampung. Lampung.

Hamalik, Oemar. (2001). Proses Belajar Mengajar. Bumi Aksara. Jakarta.

Mardapi, Djemari.(2012). Pengukuran Penelitian dan Evaluasi Pendidikan. Nuha medika. Yogyakarta.

Natalia, Yhuni Pipit. (2011). Pengembangan Lembar Kerja Siswa (LKS) Berbasis Lingkungan Sekitar Sekolah sebagai Bahan Ajar pada Materi Klasifikasi Makhluk Hidup di SMP N 3 Kembang Jepara. Jurusan Biologi FMIPA Universitas Negeri Semarang. Semarang.

Nawarda, Sardaini. (2017). Pengembangan LKPD Praktikum Berbasis Lingkungan pada Materi Asam Basa Di Kelas XI SMAN 1 Sabang. Skripsi. Universitas Islam Negeri ArRaniry Darussalam. Banda Aceh.

Nurmala, Kartika. (2018). Pengembangan Lembar Kerja Siswa (LKS) Berbasis Moodle Sebagai Media Pembelajaran Interaktif pada Materi Archaebacteria Dan Eubacteria. Fakultas Tarbiyah dan Keguruan. Universitas Islam Negeri (UIN) Raden Intan Lampung. Lampung.

Poppy Kamalia Devi, dkk.(2019), Pengembangan Perangkat Pembelajaran. P4TK IPA. Bandung.

Purwanto, Ngalim M. (2019). Prinsip-Prinsip dan Teknik Evaluasi Pengajaran. Bandung: PT. Remaja Rosdakarya

Purwoko, dkk. (2008). IPA Terpadu SMP Kelas VII. Yudhistira. Jakarta .

Prastowo, A. (2011). Panduan Kreatif Membuat Bahan Ajar Inovatif: Menciptakan Metode Pembelajaran yang Menarik dan Menyenangkan. DIVA Press. Yogyakarta.

Rahayu, Yuni Sri. (2019). Modul Pengembangan Perangkat Pembelajaran. Unesa University Press. Surabaya.

Saifuddin, Azwar. (2012). Reabilitas dan Validitas. Yogyakarta: Pustaka Pelajar

Salirawati, Das. (2010).Penyusunan dan Kegunaan LKS dalam Proses Pembelajaran. vol 1 hal

3. Program Studi kimia Universitas Negeri Yogyakarta

Diakses dari

http://staff.uny.ac.id/sites/default/files/pengabdian/dassalirawati-msi-dr/19penyusunandan-kegunaan-lks.pdf pada tanggal 25 Maret (2017).

Sanjaya, Wina. 2014. Penelitian Pendidikan. Kencana Prenada Media Grup Cet. Jakarta: 
Sardiman, A. M. (2010). Interaksi dan Motivasi Belajar Mengajar. Raja Grafindo Persada. Jakarta.

Siregar, S. (2014). Statistik Parametrik untuk Penelitian Kuantitatif. Bumi Aksara. Jakarta.

Slameto. (2010). Belajar dan Faktor-faktor yang Mempengaruhinya. Rineka Cipta. Jakarta.

Sugiyono.(2015). Metode Peneliitian \& Pengembangan Research and Development. Alfabeta. Bandung.

Suharsimi, Arikunto. (2013). Dasar-dasar Evaluasi Pendidikan Edisi 2. BumiAksara. Jakarta. Suyatno dan Jihad. (2013). Menjadi Guru Profesional. Esensi-Erlangga Group. Jakarta.

Thiagarajan S., Semmel, D. S \& Semmel, M. I, "Instructional Development for Training Teachers of Expectional Children”, Minneapolis, Minnesota: Leadership Training Institute/Special Education, University of Minnesota (1974).

Tim Abdi Guru. (2007). IPA Terpadu Untuk SMP Kelas VII, Erlangga. Jakarta.

Trianto. (2010). Mendesain Model Pembelajaran Inovatif dan Progresif. Kencana. Jakarta.

Tutik, R . (2008). Pelatihan Penyusunan Lembar Kerja Siswa (LKS) Mata Pelajaran Kimia berdasarkan KTSP bagi Guru SMK/MAK DIY. Makalah ini disajikan dalam Kegiatan Pengabdian pada Masyarakat di Ruang Sidang Kimia FMIPA UNY, 22 Agustus (2008). Yogyakarta.

Usman, Moh Uzer. (2011). Menjadi Guru Profesional. Remaja Rosdakarya. Bandung.

Wahyudi, Eko. 2014. Pengaruh Minat Belajar, Cara Belajar, Dan Kreativitas Guru Dalam Mengajar Terhadap Hasil Belajar IPS Terpadu Siswa Kelas VII SMP Islam Terpadu Fitrah Insani. Bandar Lampung Tahun Ajaran (2013)/2014. Universitas Lampung. Lampung.

Wijayanti E. \& Mundilarto. (2015). Pengembangan Instrumen Asesmen Diri dan Teman Sejawat Kompetensi Bidang Studi Pada Mahasiswa .Jurnal Penelitian dan Evaluasi Pendidikan,19(2): 129-144 